\title{
A SIMPLE AND CHEAPER IN HOUSE VARICELLA ZOSTER VIRUS ANTIBODY INDIRECT ELISA
}

\author{
Erika ONO(1), Manuel Mindlin LAFER(1), Lily Yin WECKX(1), Celso GRANATO(2,3) \& Maria Isabel de MORAES-PINTO(1)
}

\begin{abstract}
SUMMARY
We have developed a cheaper an simple in house indirect ELISA that uses the live attenuated VZV vaccine as a coating antigen.

The alternative ELISA had an agreement of $94 \%$ when compared with a commercial VZV ELISA kit. Moreover, our ELISA proved to be more reliable than the kit when assessing true negative samples.

By adding a standard serum, we were able to produce results in international units per millilitre. Also, the addition of an extra step with $8 \mathrm{M}$ urea allowed the assessment of VZV IgG avidity without excessive costs.
\end{abstract}

The cost per sample to test VZV IgG was 2.7 times cheaper with our ELISA, allowing the testing of many samples without the burden of production of VZV antigen in the laboratory.

KEYWORDS: Varicella; ELISA; Antibody avidity.

\section{INTRODUCTION}

Assessment of varicella zoster virus (VZV) antibodies is performed routinely by enzyme immunoassays (ELISA) with commercially available kits. A cheaper and as accurate alternative is the use of "in house" ELISAs. However, that requires the production of VZV antigen in tissue culture and its subsequent extraction from VZV-infected cells. Moreover, most in house ELISAs use a control for nonspecific antibody binding, a similarly prepared extract of uninfected cells ${ }^{14}$.

Production of VZV antigen is usually performed in cell lines derived from human fibroblasts (e.g., MRC5 cell line), known to be time consuming and very often not so easy to handle ${ }^{21}$.

The increasing use of a VZV vaccine in different populations has added to the necessity of measuring anti-VZV antibodies as an indicator of prior or recurrent infection, to predict susceptibility to disease, and to evaluate immune response to vaccination ${ }^{3,4,5,10,12,16,17,18,22,23}$.

We have developed a cheaper and simple alternative indirect ELISA that uses the live attenuated VZV vaccine as a coating antigen. The use of a standard reference serum allowed us to produce results in international units per millilitre (IU/mL). Finally, with the addition of an extra step with $8 \mathrm{M}$ urea, we could also assess VZV IgG avidity.

\section{MATERIAL AND METHODS}

Serum samples: Two hundred and thirty-nine serum samples were tested: 221 were from healthy adults, $122(55 \%)$ of them who referred having had varicella in the past and $99(45 \%)$ who denied previous clinical VZV infection; the remaining 18 sera were drawn from 12-month-old infants without clinical or serologic evidence of previous VZV infection.

Serum samples were collected to investigate VZV seroprevalence in different populations. All studies were approved by the Ethics Committee of the Federal University of São Paulo, in São Paulo, Brazil.

VZV ELISA kit: A Hemagen indirect ELISA kit to detect IgG VZV antibodies (Columbia, USA) was used according to the manufacturer's instructions.

High, medium and low callibrators were added together with serum samples diluted 1 in 41 , all in duplicates. A standard curve with a corresponding linear regression curve fit equation was obtained and results were calculated by interpolation of mean optical density (OD) values onto the curve fit.

Results were considered positive if they were higher than 20 arbitrary units per millilitre $(\mathrm{AU} / \mathrm{mL})$, as suggested by the kit's manufacturer. 
"In House" VZV indirect ELISA: Varicella IgG antibodies were assessed by an "in house" indirect ELISA. Immulon 296 -well microtiter plates (Dynex, USA) were coated with varicella vaccine batch VA254A41A, 10 $0^{3,3} \mathrm{PFU} / \mathrm{mL}$ (Varilrix, SmithKline Beecham, Belgium) diluted 1:100 in $0.1 \mathrm{M}$ carbonate-bicarbonate buffer, $\mathrm{pH} 9.6$, and incubated overnight at $4{ }^{\circ} \mathrm{C}$. Two-fold serial dilutions of serum samples and of varicella reference serum [in house standard calibrated against "Varicella zoster virus antibody human immunoglobulin- NIBSC reagent (90/690)"'] in 0.01M phosphate buffered saline (PBS), pH 7.2 and $0.05 \%$ Tween 20 with $1 \%$ bovine serum albumin (BSA) were added to the plate and incubated for $1 \mathrm{~h}$ at $37{ }^{\circ} \mathrm{C}$. Reference serum was added to 10 wells and serum samples were added to 3 wells, in all twofold dilutions starting at $1: 100$.

In the next step, alkaline phosphatase conjugated rabbit anti-human IgG, specific for $\gamma$-chains (Dako, Denmark) diluted 1:500 in 0.01M PBS, $\mathrm{pH} 7.2$ and $0.05 \%$ Tween 20 , was incubated for $1 \mathrm{~h}$ at $37{ }^{\circ} \mathrm{C}$. $p$ nitrophenyl-phosphate disodium (Sigma, USA) in $0.1 \mathrm{M}$ diethanolamine, $0.005 \mathrm{M}$ magnesium chloride buffer, $\mathrm{pH} 9.8$, was used as substrate in a concentration of $1 \mathrm{mg} / \mathrm{mL}$. OD was read at $405 \mathrm{~nm}$ in an immunoreader ELX-800, using $630 \mathrm{~nm}$ as a reference filter (Bio-Tek Instruments, USA).

Between steps, the plate was washed five times in 0.01M PBS, pH 7.2 and $0.05 \%$ Tween 20 . All solutions were added in a $100 \mu \mathrm{L}$ volume to microplate wells. Varicella zoster antibodies were expressed in IU/ $\mathrm{mL}$ using the curve comparison method to transform optical density in concentration units. In all plates two blank wells we always present, and mean values were subtracted from all other wells.

IgG antibody avidity: To assess varicella IgG avidity, an extra step was added to the test. An 8M urea solution in PBS was dispensed to half of all wells after serum samples had been washed out. IgG avidity index was calculated by dividing results obtained with urea addition by results without urea and multiplying them by 100 . Serum samples with avidity indices below $30 \%$ were considered with low avidity.

Protective antibody levels: Because an internationally accepted antibody level that predicts previous contact with wild varicella zoster virus or vaccine is not available, we have established a cutoff based on the following. Nineteen children who had been regularly followed up from birth and did not have evidence of previous varicella infection assessed both by clinical exam and repeated serologic testing during the first year of life were tested for varicella at 12 months of age. Cutoff of $0.2 \mathrm{IU} / \mathrm{mL}$ was calculated by adding mean antibody levels $(0.04 \mathrm{IU} / \mathrm{mL})$ to 3 standard deviations ( $3 \times 0.04 \mathrm{IU} / \mathrm{mL})$.

Assessment of VZV ELISA specificity: Because cross-reactivity among Herpesvirus antibodies has been described ${ }^{1,2}$, we have tested 8 serum samples for cytomegalovirus (CMV) IgG (CMV-IgG, Asxym, Immunofluorimetry with microparticles) and Epstein Barr viral capsid antigen (VCA) IgG (Indirect Immunofluorescence, "home made" with H3PR1 cells). Five sera were from adults without history of VZV infection who proved to be seronegative for IgG VZV by our "in house ELISA"; the other 3 sera were from 15 month old infants who had been vaccinated at 12 month of age with VZV vaccine (Varilrix, SmithKline Beecham, Belgium) and were seropositive for IgG by our "in house" VZV ELISA.

\section{RESULTS}

Comparison of "in house" ELISA with commercial ELISA kit: In house ELISA and commercial ELISA kit showed an agreement of $94 \%$. When compared with commercial kit, our in house ELISA showed a sensitivity of $95 \%$ and specifity of $87 \%$. Only 13 out of 239 samples tested produced discordant results when assessed by both ELISAs (Table 1).

Table 1

Relative performance of in house indirect ELISA in detecting varicella zoster IgG antibodies on the basis of a commercial indirect ELISA

\begin{tabular}{lcccc}
\hline & & \multicolumn{3}{c}{ Commercial Kit of indirect ELISA } \\
\hline & & Positive & Negative & Total \\
In house & Positive & 172 & 8 & 180 \\
indirect ELISA & Negative & 5 & 54 & 59 \\
\hline & Total & 177 & 62 & 239 \\
\hline
\end{tabular}

Sensitivity: 97\%; Specificity: 87\%; Agreement: $94 \%$

True positive and true negative samples assessed by "in house" ELISA and commercial ELISA kit: As described in the Materials and Methods session, we sellected among the samples tested by both methods those that were supposedly positive (adults who referred previous clinical VZV infection) and those that were supposedly negative (12-month infants without clinical and laboratory evidence of VZV infection).

While the commercial ELISA kit detected 98\% (120 in 122) supposedly positive samples and $89 \%$ (16 in 18) supposedly negative samples, our in house ELISA detected $98 \%$ (120 in 122) and 100\% (18 in 18) of the same serum samples (Table 2).

Table 2

Relative performance of in house indirect ELISA and a commercial kit of

indirect ELISA in detecting varicella zoster antibodies in samples from individuals with previous varicella infection and in children without previous varicella infection at 12 months of age

\begin{tabular}{lcc}
\hline Samples & In house ELISA & Commercial Kit \\
\hline $\begin{array}{l}\text { Supposedly positive } \\
\text { (previous varicella infection) }\end{array}$ & $120 / 122(98 \%)$ & $120 / 122(98 \%)$ \\
$\begin{array}{l}\text { Supposedly negative } \\
\text { (12 months of age without } \\
\text { history of varicella infection) }\end{array}$ & $18 / 18(100 \%)$ & $16 / 18(89 \%)$ \\
\hline
\end{tabular}

Assessment of VZV ELISA specifity: Among the 5 samples from VZV IgG seronegative adults, 4 were positive from CMV IgG and one was negative. All 5 sera were also positive for VCA IgG antibodies.

Among the 3 samples from VZV IgG seropositive children, 2 were seronegative for CMV IgG and one was positive; 2 were seronegative for VCA $\mathrm{IgG}$ and one was weakly positive (Table 3 ).

Cost assessment of "in house" ELISA and commercial ELISA kit: Our in house ELISA proved to be cheaper than the commercial kit, with a cost per sample of US\$0.99 and US\$2.70, respectively (Table 4). 
Table 3

Assessment of cross-reactivity between VZV IgG antibodies detected by our ELISA and cytomegalovirus (CMV) IgG and Epstein Barr viral capsid antigen (VCA) $\mathrm{IgG}$

\begin{tabular}{lll}
\hline VZV IgG antibodies & CMV IgG & VCA IgG \\
\hline Negative $(\mathrm{n}=5)$ & 4 positive & 5 positive \\
& 1 negative & 0 negative \\
Positive $(\mathrm{n}=3)^{*}$ & 2 negative & 2 negative \\
& 1 positive & 1 weakly positive \\
\hline
\end{tabular}

* Serum sample tested positive for CMV IgG was not the same tested weakly positive for Epstein Barr VCA IgG.

Table 4

Compared costs of varicella zoster in house indirect ELISA and commercial Kit

\begin{tabular}{lcc}
\hline $\begin{array}{l}\text { Costs and sample } \\
\text { tested per microplate }\end{array}$ & $\begin{array}{c}\text { In house } \\
\text { ELISA }\end{array}$ & $\begin{array}{c}\text { Commercial } \\
\text { kit }\end{array}$ \\
\hline Cost per microplate & US\$ 27.67 & US\$ 243.33 \\
Number of sample per microplate & 28 & 90 \\
Cost per sample & US\$ 0.99 & US\$ 2.70 \\
\hline
\end{tabular}

IgG VZV antibody avidity: By the addition of an extra $8 \mathrm{M}$ urea step, we were able to assess IgG VZV antibody avidity using the in house ELISA. As shown on Table 5, individuals with past primary VZV infection had high (above 60\%) or intermediate IgG avidity (between $30 \%$ and $60 \%$ ). Those with recent or concurrent infection showed low IgG avidity (below 30\%).

Table 5

IgG VZV antibody avidity assessed in different patients

\begin{tabular}{lcc}
\hline Patient & $\begin{array}{c}\text { VZV antibodies } \\
(\mathrm{IU} / \mathrm{mL})\end{array}$ & $\begin{array}{c}\text { VZV IgG } \\
\text { avidity }(\%)\end{array}$ \\
\hline $\begin{array}{l}\text { Adult A with VZV } \\
\text { infection in childhood }\end{array}$ & 1.4 & 62 \\
$\begin{array}{l}\text { Adult B with VZV } \\
\text { infection in childhood }\end{array}$ & 1.1 & 48 \\
$\begin{array}{l}\text { Adult C with concurrent } \\
\text { herpes zoster infection }\end{array}$ & 1.1 & 62 \\
$\begin{array}{l}\text { Child A with concurrent } \\
\text { VZV infection }\end{array}$ & 11.1 & 1.3 \\
$\begin{array}{l}\text { Child B 2 months } \\
\text { after infection VZV }\end{array}$ & 3.2 & 6.1 \\
\hline
\end{tabular}

\section{DISCUSSION}

We have developed a modified indirect ELISA that proved to be simple, cheap and easy to perform. Most "in house" ELISAs that detect antibodies against viruses require the production and extraction of virus antigen $^{6,20}$. Many laboratories do not have tissue culture facilities, precluding the use of such techniques.

However, previous immunoassays well accepted in the literature have used alternatives for less accessible reagents. In special, toxoid vaccines have been routinely used in ELISAs to detect tetanus and diphtheria antibodies $^{6-9,15}$.

Live attenuated vaccines against measles and mumps have also been used as antigens for "in vitro" $\mathrm{T}$ cell proliferation assays, with good results ${ }^{11}$.

Our modified ELISA had a good agreement when compared with a commercial ELISA kit and did not show cross-reactivity with antibodies from other Herpesviruses. Moreover, it proved to be superior than the kit when true negative samples were tested. As suggested by others ${ }^{19}$, we used sera from 12 month-old infants without evidence of previous VZV infection.

Another advantage of the test we have developed was the use of a reference serum with a known concentration antibodies measured in IU/ $\mathrm{mL}$. As it is well known, that allows the comparison of results obtained in different countries ${ }^{13}$.

Finally, introducing an extra step allowed the assessment of VZV $\mathrm{IgG}$ avidity without excessive costs.

In sum, we have developed a cheap and accurate alternative ELISA to measure VZV antibodies that proved suitable for most laboratories without the cumbersome needs of tissue culture, that produced results in $\mathrm{IU} / \mathrm{mL}$ and permitted the assess of IgG avidity.

\section{RESUMO}

\section{Desenvolvimento de ELISA indireto simples e de baixo custo para detecção de anticorpos anti-varicela zoster}

Desenvolvemos um ensaio imunoenzimático (ELISA) indireto simples e econômico para detecção de anticorpos contra o vírus da varicela zoster (VVZ) que utiliza a vacina contendo o vírus vivo atenuado como antígeno para recobrir a placa.

Este ELISA mostrou uma concordância de 94\% quando comparado com um kit de ELISA comercial para anticorpos contra varicela. Além disso, nosso ELISA mostrou ser mais confiável que o kit quando amostras comprovadamente negativas foram testadas.

O uso de um soro padrão de referência, calibrado em unidades internacionais por mililitro, possibilitou também que os resultados pudessem ser comparados com outros estudos. O acréscimo de uma etapa extra com solução de uréia $8 \mathrm{M}$ permitiu avaliação de avidez de IgG para VVZ sem custos excessivos.

O custo por amostra para testar IgG contra VVZ com nosso ELISA foi 2,7 vezes mais barato quando comparado com o kit comercial. 


\section{REFERENCES}

1. AMERICAN ACADEMY OF PEDIATRICS - Human Herpesvirus 6 (including Roseola) and 7. In: PICKERING, L.K., ed. Red Book: 2003 Report of the Committee on Infectious Diseases. 26. ed. Elk Grove Village, American Academy of Pediatrics, 2003. p. 357-358.

2. AMERICAN ACADEMY OF PEDIATRICS - Varicella-zoster infections. In: PICKERING, L.K., ed. Red Book: 2003 Report of the Committee on Infectious Diseases. 26. ed. Elk Grove Village, American Academy of Pediatrics, 2003. p. 672686.

3. AMPOFO, K.; SAIMAN, L.; LARUSSA, P. et al. - Persistence of immunity to live attenuated varicella vaccine in healthy adults. Clin. infect. Dis., 34: 774-779, 2002.

4. ASANO, Y.; SUGA, S.; YOSHIKAWA, T. et al. - Experience and reason: twenty-year follow-up of protective immunity of the Oka strain live varicella vaccine. Pediatrics, 94: 524-526, 1994.

5. BOGGER-GOREN, S.; BABA, K.; HURLEY, P. et al. - Antibody response to varicellazoster virus after natural or vaccine-induced infection. J. infect. Dis., 146: 260-265, 1982.

6. DE MORAES-PINTO, M.I.; ORUAMABO, R.S.; IGBAGIRI, F.P. et al. - Neonatal tetanus despite immunization and protective antitoxin antibody. J. infect. Dis., 171: 10761077, 1995.

7. DE MORAES-PINTO, M.I.; ALMEIDA, A.C.M.; KENJ, G. et al. - Placental transfer and maternally acquired neonatal IgG immunity in human immunodeficiency virus infection. J. infect. Dis., 173: 1077-1084; 1996.

8. GALAZKA, A.M. - The immunological basis for immunization series. Module 2: Diphtheria. Geneva, World Health Organization, 1993.

9. GALAZKA, A.M. - The immunological basis for immunization series. Module 3: Tetanus. Geneva, World Health Organization, 1993.

10. GALIL, K.; LEE, B.; STRINE, T. et al. - Outbreak of varicella at a day-care center despite vaccination. New Engl. J. Med., 347: 1909-1915, 2002.

11. GANS, H.; YASUKAWA, L.; RINKI, M. et al. - Immune responses to measles and mumps vaccination of infants at 6, 9 and 12 months. J. infect. Dis., 184: 817-826, 2001 .
12. GERSHON, A.A.; STEINBERG, S.P. \& GELB, L. - Live attenuated varicella vaccine use in immunocompromised children and adults. Pediatrics, 78: 757-762, 1986.

13. KEMENY, D.M. - Quantitation. In: Pergamon, 1991. p. 57-67.

14. KRAH, D.L. - Assays for antibodies to varicella-zoster virus. Infect. Dis. Clin. N. Amer. 10: $507-527,1996$

15. KRISTIANSEN, M.; AGGERBECK, H. \& HERON, I. - Improved ELISA for determination of anti-diphtheria and/or anti-tetanus antitoxin antibodies in sera. Acta path. microbiol. immunol. scand., 105: 843-853, 1997.

16. KUTER, B.; MATTHEWS, H.; SHINEFIELD, H. et al. - Ten year follow-up of healthy children who received one or two injections of varicella vaccine. Pediat. infect. Dis. J., 23: 132-137, 2004.

17. LEVIN, M.J.; GERSHON, A.A.; WEINBERG, A. et al. - Immunization of HIV-infected children with varicella vaccine. J. Pediat., 139: 305-310, 2001

18. REIS, A.D.; PANNUTI, C.S. \& SOUZA, V.A.U.F. - Prevalência de anticorpos para o vírus da varicela-zoster em adultos jovens de diferentes regiões climáticas brasileiras. Rev. Soc. bras. Med. trop., 36: 317-320, 2003.

19. ROBERTSON, P.W.; BELL, S.M. \& FERSON, M.J. - A method for determining the cutoff value of a varicella-zoster virus IgG enzyme immunoassay for immune status. J. virol. Meth., 26: 115-118, 1989.

20. SHANLEY, J.; MYERS, M.; EDMOND, B. \& STEELE, R. - Enzyme-linked immunosorbent assay for detection of antibody to varicella-zoster virus. J. clin. Microbiol., 15: 208-211, 1982.

21. SHEHAB, Z. \& BRUNELL, P.A. - Enzyme-linked immunosorbent assay for susceptibility to varicella. J. infect. Dis., 148: 472-476, 1983.

22. WATSON, B.; KELLER, P.M.; ELLIS, R.W. \& STARR, S.E. - Cell-mediated immune responses after immunization of healthy seronegative children with varicella vaccine: kinetics and specificity. J. infect. Dis., 162: 794-799, 1990

23. ZERBONI, L.; NADER, S.; AOKI, K. \& ARVIN, A.M. - Analysis of the persistence of humoral and cellular immunity in children and adults immunized with varicella vaccine. J. infect. Dis., 177: 1701-1704, 1998.

Received: 5 January 2004

Accepted: 14 May 2004 